\title{
Calculate of withdrawal times of clenbuterol in goats to obtain safe times of slaughter
}

\author{
Lazuardi Mochamad ${ }^{1}$, Bambang Hermanto ${ }^{2}$ and T. I. Restiadi ${ }^{3}$
}

1. Department of Basic Science, Veterinary Pharmacy Subdivision, Faculty of Veterinary Medicine, Universitas Airlangga, Surabaya, Indonesia; 2. Department of Pharmacology, Faculty of Medicine, Universitas Airlangga, Surabaya, Indonesia; 3. Department of Reproduction, Faculty of Veterinary Medicine, Airlangga University, Surabaya, Indonesia.

Corresponding author: Lazuardi Mochamad, e-mail: lazuardi@fkh.unair.ac.id

Co-author: BH: bambanghermanto506@gmail.com, TIR: tjukir@yahoo.com

Received: 10-01-2018, Accepted: 24-04-2018, Published online: 01-06-2018

doi: 10.14202/vetworld.2018.731-738 How to cite this article: Mochamad L, Hermanto B, Restiadi TI (2018) Calculate of withdrawal times of clenbuterol in goats to obtain safe times of slaughter, Veterinary World, 11(6): 731-738.

\begin{abstract}
Background and Aim: Clenbuterol as a $\beta_{2}$-agonist drug was investigated according to the concentration of the drug available in the bodies of goats and according to the level of sensitivity of the instruments used for detection. The objective of the current study was to determine withdrawal times after giving a therapeutic dose that resulted in safe slaughters.

Materials and Methods: Five healthy male goats with a mean body weight of $20.64 \mathrm{~kg}$ were treated with a single dose of $5.10^{-3} \mathrm{mg} / \mathrm{kg}$ in the BW onto jugular vein. Whole blood samples of approximately $5 \mathrm{~mL}$ were taken in a time series at 5,30 , $60,90,150,210,270,390,510,630$, and $750 \mathrm{~min}$. At $24 \mathrm{~h}$ posttreatment, all subjects were sacrificed, and $300 \mathrm{~g}$ samples of the liver were obtained. The plasma concentration and liver residue of the drug were observed by reverse-phase highperformance liquid chromatography.

Results: The drug reached a maximum concentration of $19.233 \pm 0.331 \mu \mathrm{g} / \mathrm{mL}$ at $5 \mathrm{~min}$, and the elimination half-life was at $173.25 \mathrm{~min}$. The limit detection was obtained at $0.053 \mu \mathrm{g} / \mathrm{mL}$. A one-way analysis of variance between all goats showed that elimination of the clenbuterol in their bodies was similar $(\mathrm{p}=1.00)$, with a withdrawal time of $1,479.326$ min and no residues in the liver $(\mathrm{p}<0.05)$.
\end{abstract}

Conclusion: Safe times for slaughter were determined to be at 2 days, $13 \mathrm{~h}$, and $12 \mathrm{~min}$ as the $2^{\text {nd }}$ safety factor (SF) time and 3 days, $1 \mathrm{~h}$, and $58 \mathrm{~min}$ as the $3^{\text {rd }} \mathrm{SF}$ time with the liver organ free from residue.

Keywords: elimination half-life, new method for calculating withdrawal time, prescriptions for obtained $\beta_{2}$-agonist, residues in liver.

\section{Introduction}

One health system for human health concepts involved using all aspects that can drive the quality of health improvement. Food is a major aspect that can directly affect human health, especially the presence or absence of harmful chemical residues including veterinary drugs. We know that a $\beta_{2}$-agonist is an active substance and it is commonly used only as a veterinary therapeutic agent. However, some users have abused the $\beta_{2}$-agonist as a veterinary drug using it as a growth-promotion agent [1]. For example, ractopamine is a veterinary drug promoted for use as a supplement for growth promotion [2]. Some countries in Europe and South-East Asia have identified residues from selected veterinary drugs and have banned all residues veterinary drug products such as ractopamine $[3,4]$. Clenbuterol has been sold as a $\beta_{2}$-agonist agent, not for growth promotion but for therapy of diseases in large polygastric animal species, for example,

Copyright: Mochamad, et al. Open Access. This article is distributed under the terms of the Creative Commons Attribution 4.0 International License (http://creativecommons.org/licenses/ by/4.0/), which permits unrestricted use, distribution, and reproduction in any medium, provided you give appropriate credit to the original author(s) and the source, provide a link to the Creative Commons license, and indicate if changes were made. The Creative Commons Public Domain Dedication waiver (http:// creativecommons.org/publicdomain/zero/1.0/) applies to the data made available in this article, unless otherwise stated. goats, cows, and cattle. Clenbuterol has been legally used in horses, a large monogastric animal species. The hazard of using clenbuterol in large polygastric animals needs to be determined to assess the risk of drug residues in the product, which has implications for human health. Problems with the use of clenbuterol in animals intended for human consumption, i.e., the withdrawal time, suggest safety factors (SFs) in the consumption of veterinary products, i.e., meat, eggs, and milk, after the administration of a $\beta_{2}$-agonist as a therapeutic agent [5]. The withdrawal time for clenbuterol in large polygastric animals has not been determined. That timing is very important because it can be used to predict when animals can be slaughtered after receiving clenbuterol [6]. Goats are a polygastric species and are one of the consumption animals in which SF levels have not been determined yet [7].

Focusing on residues of clenbuterol, it is known that residues of the active substance in meat are not destroyed at $100^{\circ} \mathrm{C}$. Due to its physicochemical properties; clenbuterol does not melt at a temperature of $100^{\circ} \mathrm{C}$. Some clenbuterol, especially the 1-(4-amino-3,5-dichlorophenyl)- $\mathrm{R}$, is known for its difficulty in being metabolized by substitution or conjugation and having a melting point $>100^{\circ} \mathrm{C}$. Compounds of 1-(4-amino-3,5-dichlorophenyl)-R are very stable. As a consequence of their physical and chemical 
characteristics, the compound was not easy to metabolize. Characterized compounds of 1-(4-amino-3,5-dichlorophenyl)- $\mathrm{R}$ were at risk to result in metabolite residues [8-10].

Based on the problems identified above, we sought to identify the withdrawal level SF of clenbuterol when treating a local breed of goats. For clarification of the residues in the organ, we also check liver levels.

\section{Materials and Methods \\ Ethical approval}

In order to guarantee a safe, correct and carefully handling of the goats, authors proceeded according to specification of International Ethics Guidelines (Internal Ethical Committee From Faculty of Veterinary Medicine, Universitas Airlangga by Clearance Recommended No. 604-KE, August 11 ${ }^{\text {th }}$, 2016).

\section{Animals and experimental design}

The research was carried out in facilities at the Institute for Tropical Diseases Center at the Universitas Airlangga and Center for Research, Applications and Services Veterinary Pharmacy Laboratory at Faculty of Veterinary Pharmacy in Universitas Airlangga, Surabaya, Indonesia. The room temperature of the laboratory ranged from $23^{\circ} \mathrm{C}$ to $25^{\circ} \mathrm{C}$ at a relative indoor humidity of $48 \%-50 \%$. This study was conducted in compliance with the animal ethics clearance from the Faculty of Veterinary Medicine, Universitas Airlangga (Authorization register $604 \mathrm{KE}$ ). The goats were identified as Etawah goats, a local Indonesian breed, with the following characteristics: Male, 18 months of age, and in a healthy condition (average body weight of $20-21 \mathrm{~kg}$ or at mean $20.64 \pm 0.47 \mathrm{~kg}$ ) under oversight veterinary practices. The animals adapted for 2 weeks to housing in a hygienic stable. The experimental design included a time series with observations was made at 5, 30, 60, 90, 150, 210, 270, 390, 510, 630, and 750 min posttreatment with the elimination halflife $\left(\mathrm{T}_{1 / 2 \beta}\right)$ through calculating the elimination rate constant $\left(\mathrm{K}_{\mathrm{el}}\right)$ of the drugs from 5 goats [11]. The time of $5 \mathrm{~min}$ after treatment, as referred by Lazuardi [12], explained that 0-5 min of i.v. administration was representative of leg time. For postmortem residue analysis of the drug in organs, $300 \mathrm{~g}$ of liver from each goat were explored after necropsy of the cadaver at $24 \mathrm{~h}$ posttreatment.

\section{Analysis of clenbuterol and the validation method}

Pure clenbuterol as a reference material dissolved in non-matrix biologic was determined by spectrophotometry at a specific wavelength using a Shimadzu ultraviolet (UV)-1800 through scanning in the wavelength range $200.0 \mathrm{~nm}-245.0 \mathrm{~nm}$. Clenbuterol in plasma was measured with high-performance liquid chromatography (HPLC) using a Shimadzu CBM-20A Communication Bus Module for interaction with a photodiode array detector UV-visible M20A, in which a LiChrospher ${ }^{\circledR} 100$ RP-18 column was a perfect fit. The following settings were applied with the isocratic method: $0.5 \mathrm{~mL} / \mathrm{min}$ flow rate and $300 \mathrm{kgf} / \mathrm{c}$ maximum pump at a wavelength of $223.0 \mathrm{~nm}$. All chemicals were of high-purity grade, and clenbuterol was a certified reference material of the European Pharmacopoeia level CAS No. 2189819-1. The mobile phase of the fraction used acetonitrile: water (30:70) containing $0.10 \%$ phosphoric acid at $\mathrm{pH} 3.8$ [13]. The analyte solvent was acetonitrile analytic grade: water for chromatography at a composition fraction $30 \%: 70 \%$ containing $0.10 \%$ phosphoric acid adjusted in an acid condition with $\mathrm{pH}$ ranging from $\mathrm{pH} 3.8$ to $\mathrm{pH}$ 4.0. Artificial plasma of the goats free from drug residues was obtained from the Central of Veterinary Pharmaceutical, Directorate General of Livestock Services, Republic Indonesia at Ahmad Yani Rd Surabaya, Indonesia. Liver organs free from the residue of the drug as medium matrix biology were obtained from a goat slaughterhouse that belonged to the Surabaya Government in Pegirian Rd, Surabaya, Indonesia.

Validation methods started from the $4^{\text {th }}$ point test as follows: (a) Linearity test to determine the relationship between concentration of analytes to the response detector, (b) intraday precision test, (c) accuration test by assessed recovery levels, and (d) sensitivity test using the method limit of detection (LOD) and limit of quantification (LOQ). Points $a, b$, and $c$ of the validation method were using triplo iteration between concentrations $0.25 \mu \mathrm{g} / \mathrm{mL}$ and $1.00 \mu \mathrm{g} / \mathrm{mL}$ using the artificial plasma from the goats and liver organs free from residue of the drug as medium matrix biology [14]. The sensitivity tests used mobile phase solvent of the HPLC system from $\mathrm{pH} 3.8$ to $\mathrm{pH} 4.00$.

\section{Determination of withdrawal time and analysis resi- due from livers}

Clenbuterol injections of $50 \mathrm{~mL}$ containing clenbuterol-HCl $0.02651 \mathrm{mg} / \mathrm{mL}$ of clenbuterol-HCl were obtained from Grovet BV, the Netherlands with a recommended dose of $5.10^{-3} \mathrm{mg}$ clenbuterol- $\mathrm{HCl} / \mathrm{kg}$ body by route of intravenous. Blood samples $(5 \mathrm{~mL})$ were collected in glass heparin vacutainer tubes; then the plasma was separated from the whole blood through centrifuging at $1300 \times \mathrm{g}$ and kept in a refrigerator at $-20^{\circ} \mathrm{C}$ until the preparations. At $24 \mathrm{~h}$ posttreatment, all subjects were sacrificed, and necropsies were performed to obtain liver organs. The liver organ was placed in an area $2 \mathrm{~cm}$ from the portal vein and marked as code liver- 1 to code liver-5 as specimens from subjects no 1 to 5 then directly kept in an inactive bottle (dark glass sample bottle) in a cold room at $4^{\circ} \mathrm{C}$ until preparation [15].

The LOQ was assessed from the lowest concentration of an analyte in a sample that could be determined from the chromatogram area. The determination of low concentrations of analyte required that the highest ratio of the analyte peak versus the noise peak was $\geq 5$. The mobile phase eluent was injected 3 times, and analysis was obtained by visual evaluation 
of Np-p using the width of the $20^{\text {th }}$ analyte on the chromatogram. The blank was injected 3 times to obtain the standard deviation of the blank signal $\left(\mathrm{S}_{\mathrm{B}}\right)$. Next, two other concentrations, an upper and lower concentration of the analyte, were injected to obtain the sensitivity slope (S). The last step was to calculate the LOD and LOQ limit from the equation below with $\mathrm{k}=3$ as the constant. The LOQ was calculated from 3 times the $\mathrm{LOD}$, with $\mathrm{LOD}=\mathrm{k} \times\left(\frac{\mathrm{S}_{\mathrm{B}}}{\mathrm{S}}\right)$ as referenced from new techniques reported in the previous studies [14-17].

Sample preparation from plasma included the following process: First, the solid-phase extraction (SPE) column SOLA HRP $10 \mathrm{mg} / \mathrm{mL}$ cartridge was activated by adding $1 \mathrm{~mL}$ of methanol continuously, $1 \mathrm{~mL}$ water, and then $1 \mathrm{~mL}$ of sample. Second, the SPE column was dried in a warm temperature in an incubator for $30 \mathrm{~min}$ before beginning the elution. Finally, the SPE column was used to elute $1 \mathrm{~mL}$ of the mobile phase, and the eluent containing the active substance was collected and then dried, yielding a sample ready for use. The standard curve in the plasma matrix for the concentration versus the response detector was analyzed by the regression-correlation method with Minitab 18.0 (significant at 0.05 ). For determination of the withdrawal time, the following equation of 1 at SF 2 or 3 and the data maximum concentration $\left(\mathrm{C}_{0}\right)$ at the first sampling, $\mathrm{T}_{1 / 2 \beta}$ were used at $0.693 / \mathrm{K}_{\mathrm{el}}$. The equation notation indicated that the Ln $\mathrm{R}$ accumulation factor at $24 \mathrm{~h}$ was approximately $1.306 \pm 0.05$ and the $\mathrm{C}_{\lim }$ was the LOQ [18]. The $\mathrm{K}_{\mathrm{el}}$ was calculated from the slope of the exponential equation from the regression concentration versus time.

Withdrawal time $=\frac{\mathrm{T}_{1 / 2^{2}} \times\left(\mathrm{LnR} \times \mathrm{C}_{0}-\mathrm{LnC}_{\text {lim }}\right)}{\mathrm{Ln} 2} \times \mathrm{SF}$

Sample preparation for monitoring drug residues in livers of the goats after the last sampling was prepared as follows: $300 \mathrm{~g}$ of the specimen from part of the liver portal vein area were blended in a mortar at $500 \mathrm{~g}$, then the $100 \mathrm{~mL}$ of methanol was added and directly shacked for $30 \mathrm{~min}$. Mixtures of samples were centrifuged at $1300 \times g$ for $15 \mathrm{~min}$, and then, the supernatant was collected and kept in a box of ice at $20^{\circ} \mathrm{C}$. The SPE was activated by adding $1 \mathrm{~mL}$ of methanol, and then, $3 \mathrm{~mL}$ of water was added for chromatography. Then, $1 \mathrm{~mL}$ of the supernatant of the samples was added to SPE, and elution was performed at $3 \mathrm{~mL}$ in the mobile phase of HPLC. Filtrates from elution of the mobile phase solution were collected in special tubes and drying by nitrogen gas and ready to inject onto the HPLC system.

\section{Results}

The results of these observations using spectrophotometer UV-visible showed that the wavelength selected was $223 \mathrm{~nm}$. That wavelength was not intervening to other compounds, and some researchers have already used that wavelength to identify clenbuterol by HPLC in plasma [19]. An analysis with HPLC showed the retention time of clenbuterol from the injection dose regimen was found to be approximately $\pm 12 \mathrm{~min}$ (Figures-1 and 2). The low clenbuterol concentration dissolved in the mobile phase but still had an available chromatogram area of approximately $0.001 \mu \mathrm{g} / \mathrm{mL}$ at 33.925. Two concentrations, the upper and lower, were determined to be $0.002 \mu \mathrm{g} / \mathrm{mL}$, with areas of 67.850 , and $0.05 \mu \mathrm{g} / \mathrm{mL}$, with an area of 1696.258 . The regression analysis showed that $R^{2}=0.99(\mathrm{p}<0.05)$ at $Y=-0.000246+33925 \mathrm{X}$. The standard deviation of the triple blank injection signals was $0.2 \mathrm{~mm}$ when calculated with $N p-p$ at the $20^{\text {th }}$ peak analyte width ( $0.4 \mathrm{~mm}, 0.6 \mathrm{~mm}$, and $0.8 \mathrm{~mm}$ ).

The detection limit was obtained as follows: $3 \times\left(\frac{0.2}{33925}\right)=0.0177 \mu \mathrm{g} / \mathrm{mL}$, and the quantitation limit was $0.053 \mu \mathrm{g} / \mathrm{mL}$. The precision and recovery values of the clenbuterol from the goat plasma

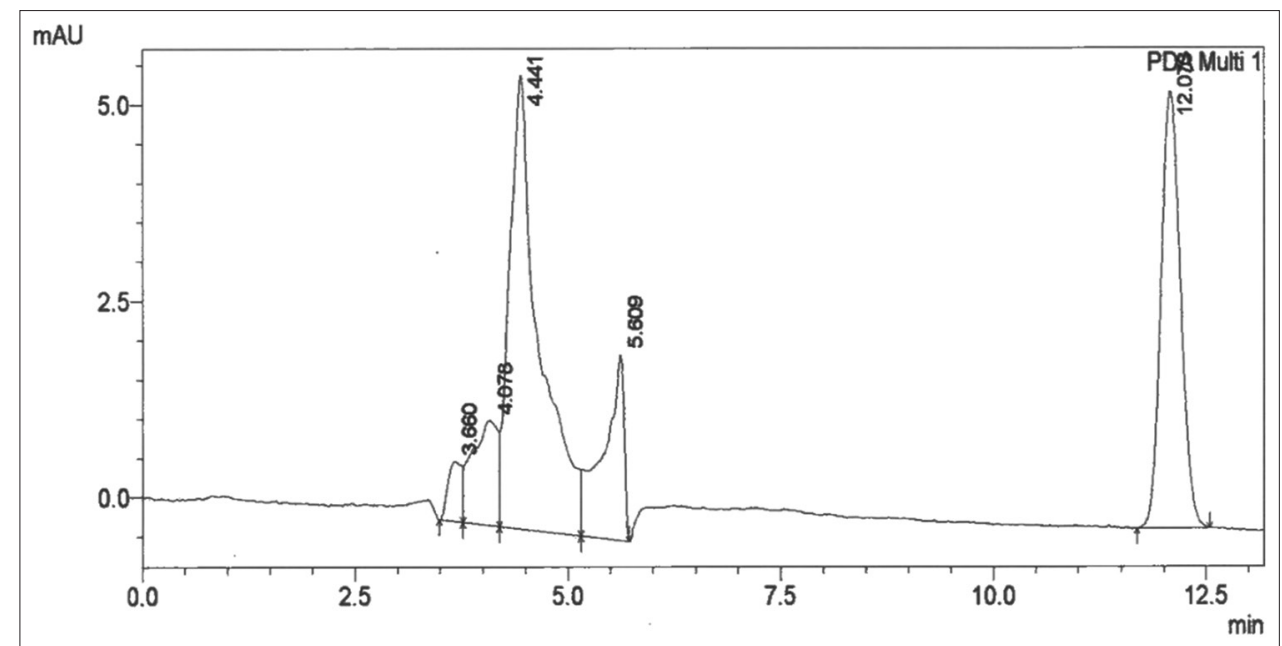

Figure-1: Retention time of clenbuterol at $1.0 \mu \mathrm{g} / \mathrm{mL}$ in goat plasma using the isocratic method high-performance liquid chromatography-photodiode array ultraviolet-visible detector $(223 \mathrm{~nm})$ at acetonitrile:water (30:70) containing $0.10 \%$ phosphoric acid $\mathrm{pH} 3.8$ in a laboratory room at $23^{\circ} \mathrm{C}-25^{\circ} \mathrm{C}$ and $46 \%$ humidity levels. 
are summarized in Table-1. The calibration curve from data in Table-1, at a mean observed concentration $(\mathrm{X})$ versus a mean area chromatogram $(\mathrm{Y})$ by regression analysis was obtained using equation $\mathrm{Y}=-5379+33941150 \mathrm{X} \quad\left(R^{2} \quad 0.99 ; \quad \mathrm{p}<0.05\right)$. Table-2 shows the calibration curve of the clenbuterol in liver organs free from the residue of the drug as medium matrix biology. The mean of the observed concentration $(\mathrm{X})$ versus mean of the area chromatogram $(\mathrm{Y})$ was obtained with equation $\mathrm{Y}=-848+33832950 \mathrm{X}$ at $R^{2} 0.99(\mathrm{p}<0.05)$.

The average plasma concentration of the clenbuterol determined at various times following intramuscular administration is presented in Table-3 (Figure-3). The concentrations at $5 \mathrm{~min}$ of dosing had a mean of $19.233 \pm 0.331 \mu \mathrm{g} / \mathrm{mL}$. The mean of the

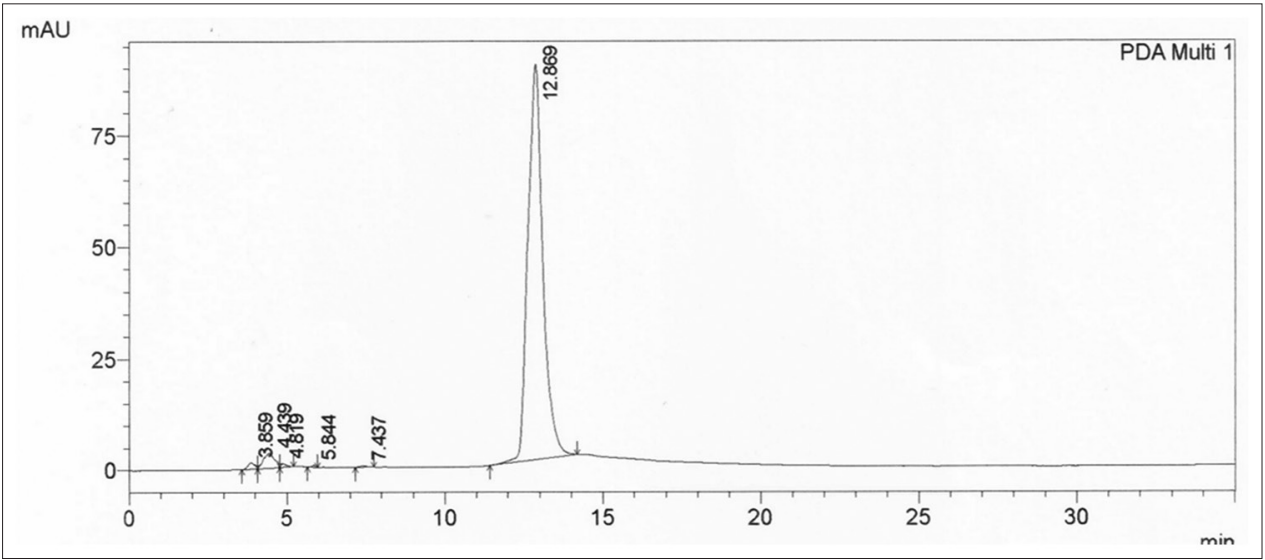

Figure-2: Clenbuterol 0.75 ppm in plasma after being separated with solid-phase extraction C18 1 mg was presented at $12.00 \mathrm{~min}$, and there were no impurity peaks during the monitored 35 min until the stop time.

Table-1: Calculated concentrations and observed concentrations for intraday precision and recovery analysis in artificial plasma.

\begin{tabular}{|c|c|c|c|c|}
\hline Drug & $\begin{array}{c}\text { Calculate } \\
\text { concentration }\end{array}$ & $\begin{array}{c}\text { Observed } \\
\text { concentration }(X)\end{array}$ & $\begin{array}{c}\text { Area } \\
\text { chromatogram }(\mathrm{Y})\end{array}$ & Recovery (\%) \\
\hline \multirow[t]{11}{*}{ Clenbuterol in goat plasma } & $0.250 \mu \mathrm{g} / \mathrm{mL}$ & 0.230 & 7802790.027 & 92.000 \\
\hline & & 0.240 & 8142041.767 & 96.000 \\
\hline & & 0.235 & 7972415.897 & 94.000 \\
\hline & Mean $\pm \%$ CV & $0.235 \pm 2.128$ & $7972415.897 \pm 2.128$ & $94.000 \pm 2.128$ \\
\hline & $0.500 \mu \mathrm{g} / \mathrm{mL}$ & 0.480 & 16284083.531 & 96.000 \\
\hline & & 0.500 & 16962587.012 & 100.000 \\
\hline & & 0.490 & 16623335.271 & 98.000 \\
\hline & Mean $\pm \%$ CV & $0.490 \pm 2.041$ & $16623335.270 \pm 2.041$ & $98.000 \pm 2.041$ \\
\hline & $1.000 \mu \mathrm{g} / \mathrm{mL}$ & 1.010 & 34264425.751 & 101.000 \\
\hline & & 0.980 & 33246670.530 & 98.000 \\
\hline & & 0.990 & 33585922.271 & 99.000 \\
\hline Mean $\pm \%$ CV & & $0.993 \pm 1.538$ & $33699006.180 \pm 1.538$ & $99.330 \pm 1.538$ \\
\hline
\end{tabular}

$\mathrm{Y}=-5379+33941150 \times\left(R^{2} 0.99 ; \mathrm{p}<0.05\right), \mathrm{CV}=$ Coefficient of variation

Table-2: Calculated concentrations and observed concentrations for intraday precision and recovery analysis in liver organs free from the residue of the drug as medium matrix biology.

\begin{tabular}{|c|c|c|c|c|}
\hline Drug & $\begin{array}{c}\text { Calculate } \\
\text { concentration }\end{array}$ & $\begin{array}{c}\text { Observed } \\
\text { concentration }(\mathrm{X})\end{array}$ & $\begin{array}{c}\text { Area } \\
\text { chromatogram (Y) }\end{array}$ & Recovery (\%) \\
\hline \multirow{11}{*}{$\begin{array}{l}\text { Clenbuterol in liver organ } \\
\text { free from residue of the } \\
\text { drug }\end{array}$} & $0.025 \mu \mathrm{g} / \mathrm{mL}$ & 0.024 & 814204.177 & 96.000 \\
\hline & & 0.018 & 610783.232 & 72.000 \\
\hline & & 0.020 & 678113.470 & 80.000 \\
\hline & Mean $\pm \%$ CV & $0.021 \pm 14.782$ & $701033.626 \pm 14.782$ & $82.667 \pm 14.782$ \\
\hline & $0.050 \mu \mathrm{g} / \mathrm{mL}$ & 0.042 & 1435857.307 & 84.000 \\
\hline & & 0.051 & 1730183.875 & 102.000 \\
\hline & & 0.048 & 1628408.353 & 96.000 \\
\hline & Mean $\pm \%$ CV & $0.047 \pm 9.750$ & $1598149.845 \pm 9.353$ & $94.000 \pm 9.750$ \\
\hline & $1.000 \mu \mathrm{g} / \mathrm{mL}$ & 0.998 & 32757223.650 & 99.800 \\
\hline & & 0.970 & 33916417.790 & 97.000 \\
\hline & & 0.989 & 33400967.100 & 98.900 \\
\hline Mean $\pm \%$ CV & & $0.986 \pm 1.450$ & $33358202.850 \pm 1.741$ & $98.567 \pm 1.450$ \\
\hline
\end{tabular}

$\mathrm{Y}=-848+33832950 \times\left(R^{2} 0.99 ; \mathrm{p}<0.05\right), \mathrm{CV}=$ Coefficient of variation 


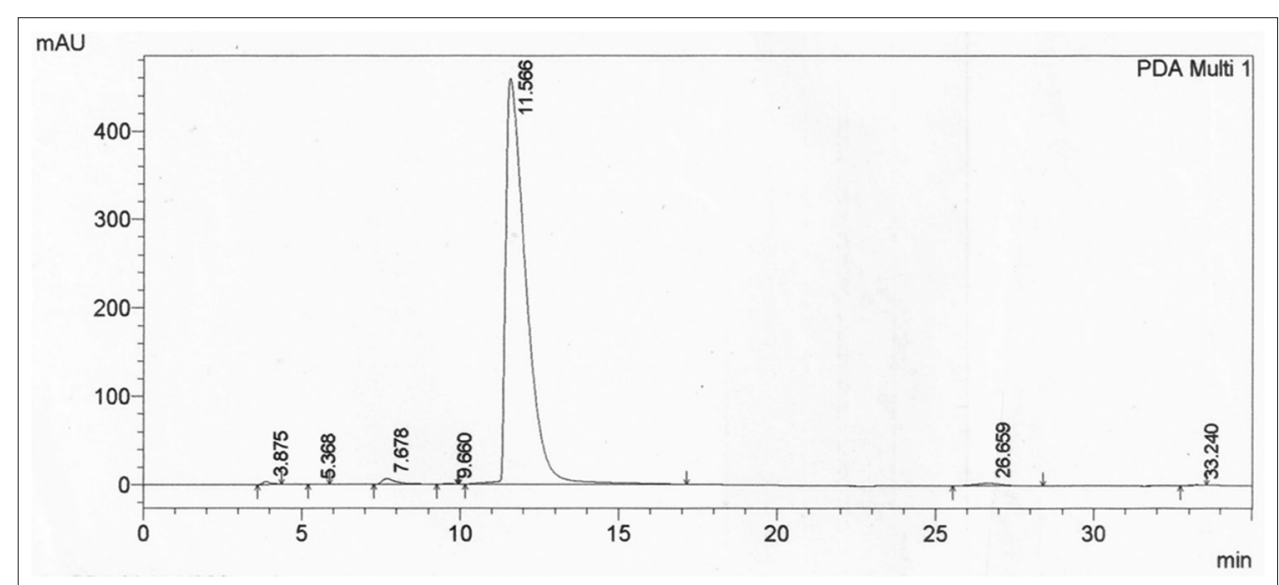

Figure-3: The clenbuterol $0.900 \mathrm{ppm}$ in a liver free from residues of the drug in matrix biology showed impurities from the matrix biology at a retention time of $26.659 \mathrm{~min}$ and $33.240 \mathrm{~min}$. However, the clenbuterol was still available at a retention time of $11.566 \mathrm{~min}$.

Table-3: The concentration of clenbuterol in goats after giving a single dose of $0.02 \mathrm{mg}$ intravenously.

\begin{tabular}{|c|c|c|c|c|c|c|}
\hline \multirow[t]{2}{*}{ Time (min) } & \multicolumn{6}{|c|}{ Concentration of clenbuterol $(\mu \mathrm{g} / \mathrm{mL})$} \\
\hline & $\begin{array}{c}\text { Goat I } \\
(20.5 \mathrm{~kg})\end{array}$ & $\begin{array}{l}\text { Goat II } \\
(21.2 \mathrm{~kg})\end{array}$ & Goat III (20.5) & $\begin{array}{l}\text { Goat IV } \\
(20.0 \mathrm{~kg})\end{array}$ & $\begin{array}{c}\text { Goat V } \\
(21.0 \mathrm{~kg})\end{array}$ & $\begin{array}{c}\text { Mean } \pm \text { SD } \\
(20.64 \pm 0.47 \mathrm{~kg})\end{array}$ \\
\hline 5 & $19.021^{a}$ & $19.032^{\mathrm{b}}$ & $19.201^{c}$ & $19.101^{d}$ & $19.811^{\mathrm{e}}$ & $19.233 \pm 0.331$ \\
\hline 30 & $18.700^{\mathrm{a}}$ & $18.601^{\mathrm{b}}$ & $18.502^{c}$ & $18.021^{d}$ & $18.032^{\mathrm{e}}$ & $18.371 \pm 0.322$ \\
\hline 60 & $17.202^{\mathrm{a}}$ & $16.301^{\mathrm{b}}$ & $18.101^{\mathrm{c}}$ & $18.011^{\mathrm{d}}$ & $17.020^{\mathrm{e}}$ & $17.327 \pm 0.746$ \\
\hline 90 & $16.051^{a}$ & $16.111^{\mathrm{b}}$ & $17.001^{\mathrm{c}}$ & $17.902^{d}$ & $16.401^{\mathrm{e}}$ & $16.693 \pm 0.773$ \\
\hline 150 & $14.001^{\mathrm{a}}$ & $14.092^{\mathrm{b}}$ & $15.201^{c}$ & $16.151^{d}$ & $15.091^{\mathrm{e}}$ & $14.907 \pm 0.888$ \\
\hline 210 & $9.502^{\mathrm{a}}$ & $8.191^{\mathrm{b}}$ & $7.450^{\circ}$ & $8.201^{d}$ & $9.201^{\mathrm{e}}$ & $8.509 \pm 0.834$ \\
\hline 270 & $6.001^{\mathrm{a}}$ & $5.501^{\mathrm{b}}$ & $6.501^{c}$ & $6.801^{d}$ & $6.591^{\mathrm{e}}$ & $6.279 \pm 0.525$ \\
\hline 390 & $3.801^{\mathrm{a}}$ & $2.870^{\mathrm{b}}$ & $3.112^{c}$ & $2.812^{\mathrm{d}}$ & $3.902^{\mathrm{e}}$ & $3.299 \pm 0.518$ \\
\hline 510 & $1.701^{\mathrm{a}}$ & $1.891^{\mathrm{b}}$ & $1.911^{\mathrm{c}}$ & $1.861^{\mathrm{d}}$ & $1.840^{\mathrm{e}}$ & $1.841 \pm 0.083$ \\
\hline 630 & $1.530^{\mathrm{a}}$ & $1.601^{\mathrm{b}}$ & $1.671^{c}$ & $1.651^{\mathrm{d}}$ & $1.630^{\mathrm{e}}$ & $1.617 \pm 0.055$ \\
\hline 750 & $0.901 a$ & $0.801^{b}$ & $0.851^{c}$ & $0.951^{d}$ & $0.901^{\mathrm{e}}$ & $0.881 \pm 0.057$ \\
\hline
\end{tabular}

Superscripts of the $a, b, c, d$, e by one-way ANOVA were similar at $F=0.01(p=1.00)$, Goat-1 $Y=21.92$. $\mathrm{e}^{-0.004 \mathrm{x}},\left(R^{2}=0.983\right)$, Goat-2 $\mathrm{Y}=21.135 . \mathrm{e}^{-0.004 x},\left(R^{2}=0.9805\right)$, Goat-3 $\mathrm{Y}=21.986 . \mathrm{e}^{0.004 \mathrm{x}},\left(R^{2}=0.978\right)$, Goat-4 $\mathrm{Y}=22.223$. e- $0.004 x,\left(R^{2}=0.9684\right)$., Goat-5 Y=22.319.e- ${ }^{0.004 x},\left(R^{2}=0.9848\right)$

Table-4: Observed $24 \mathrm{~h}$ posttreatment residues of the drug in all livers.

\begin{tabular}{lc}
\hline Subject sample & Result $(\mu \mathbf{g} / \mathbf{m L})$ \\
\hline Code liver-1 from subjects 1 & $0^{\mathrm{a}}$ \\
Code liver-2 from subjects 2 & $0^{\mathrm{b}}$ \\
Code liver-3 from subjects 3 & $0^{\mathrm{c}}$ \\
Code liver-4 from subjects 4 & $0^{\mathrm{d}}$ \\
Code liver-5 from subjects 5 & $0^{\mathrm{e}}$ \\
\hline
\end{tabular}

Superscript at the same column was identical $(p<0.05)$

elimination rate constant $\left(\mathrm{K}_{\mathrm{el}}\right)$ from all goats ranged from 5 min to 750 min after dosing was obtained at $0.004 /$ min compared to the elimination half-life measured at $173.25 \mathrm{~min}$. The measured withdrawal times were obtained at 1 day $h$ and 35 min for $1^{\text {st }}$ time SF, but the $2^{\text {nd }}$ time of SF was found at 2.055 days after dosing, and the $3^{\text {rd }}$ time of SF was obtained 3.082 days after dosing.

Figure-3 shows the retention time of clenbuterol in the matrix liver free from drug residues was found at $11.566 \mathrm{~min}$. Monitored residue drugs in the liver are presented in Table-4. The results in Table-4 show the one-sample t-test for all samples was identical.

\section{Discussion}

This assessment of withdrawal times depended on the following two aspects: (a) The method for determining the analyte and (b) the sensitivity of the analytical instrument for detecting the analyte. Our method for determining the concentration of clenbuterol in plasma was suitable for the test. The last assessment was measuring the existence of the drug residue in the liver organ.

We found that the retention time chromatogram of the analyte was available for 11-12 min as shown in Figure-1. The chromatogram of the analyte from the goats was never overlayid with other impurity peaks from the biology matrix of the biology compound $[19,20]$. Figure- 2 shows that impurity peaks at more than 12 min until the stop time at 35 min were not found. Figure-3 shows that impurity that peak at a retention time of $26.669 \mathrm{~min}$ and $33.240 \mathrm{~min}$ were separated from the analyte peak. The impurities peak in picture 4 was possibly part of the matrix liver compound and not be derived from the metabolite clenbuterol. The international requirements 
mentioned that the conditions of the resolution $(\alpha)$ should not be the same with 1 or $\alpha \neq 1$ [20]. The correlation-regression analysis of clenbuterol at $0.25 \mu \mathrm{g} /$ $\mathrm{mL}-1.00 \mu \mathrm{g} / \mathrm{mL}$ from the plasma matrix was linear at $R^{2}(\mathrm{p}<0.05)$ with recovery between $94.000 \pm 2.128 \%$ and $99.330 \pm 1.538 \%$ of each concentrate [21]. Then, the $R^{2}$ of the correlation-regression for analysis of clenbuterol in the liver matrix as a blank compound was 0.99 at $\mathrm{p}<0.05$ (Table-2). The recovery of the liver matrix compound ranged from $82.667 \pm 14.782 \%$ to $98.567 \pm 1.450 \%$. The results from HPLC, shown in Table-1, indicated that the calculated concentrations between the observed concentration were recommended; thus, concentrations lower than $0.235 \mu \mathrm{g} / \mathrm{mL}$ or higher than $0.933 \mu \mathrm{g} / \mathrm{mL}$ are not recommended as precise and accurate $(p<0.05)$. The residue clenbuterol in the liver matrix within the range of observed concentrations, described in Table-2, is recommended, but concentrations lower than $0.021 \mu \mathrm{g} / \mathrm{mL}$ or higher than $0.986 \mu \mathrm{g} / \mathrm{mL}$, are not recommended as precise and accurate $(\mathrm{p}<0.05)$. Precise and accurate analysis in matrix biology (plasma or organ matrix biology) was available approximately at more than $20 \%$ of the coefficient of variation $(\mathrm{CV})$, and approximate recovery was in the range $80-120 \%$. At low concentrations, there were large $\mathrm{CV}$ values, so at high concentration values, there were small $\mathrm{CV}$ values $[16,20,22]$. The sensitivity of the test, according to measurements of the detection limit and quantification limit, was similar to that of a study reported in 2016 [23]. The results of this research indicated that the HPLC method for determining analytes in matrix biology (plasma and matrix livers free from drug residues) were suitable for the test.

Profile concentrations of clenbuterol in the plasma were apparent in two intravascular compartment models as follows: In the central compartment, the clenbuterol is rapidly distributed throughout the body, and the drug is then gradually eliminated from the body as a peripheral compartment $\left(R^{2} 0.97-0.98\right) .5 \mathrm{~min}$ after dosing, the maximum concentration obtained was $19.232 \pm 0.331 \mu \mathrm{g} / \mathrm{mL}$ with elimination continuing rapidly as presented in Figure-4 [24]. A decreased mean concentration level of $3.84 \%$ resulted from the dose and produces initial concentration levels of less than the dose after 5 min posttreatment. These levels occurred because of the drug spreading instantly throughout the body through the bloodstream after intravenous administration $[25,26]$. Drugs with strong macromolecule-drug bonds tend to decrease rapidly after the initial administration of drugs such as clenbuterol as an analog [17]. Table-2 shows that the elimination half-life was obtained at $2 \mathrm{~h}$ and $48 \mathrm{~min}$, which was less time than for other reported research. Research reports have described the elimination halflife occurring on average at $16 \mathrm{~h}-105 \mathrm{~h}$ in cattle that were administered the drug at $8 \mu \mathrm{g} / \mathrm{kg} \mathrm{BW}$ twice a day. These differences occur because of differences between species and dose regimens.

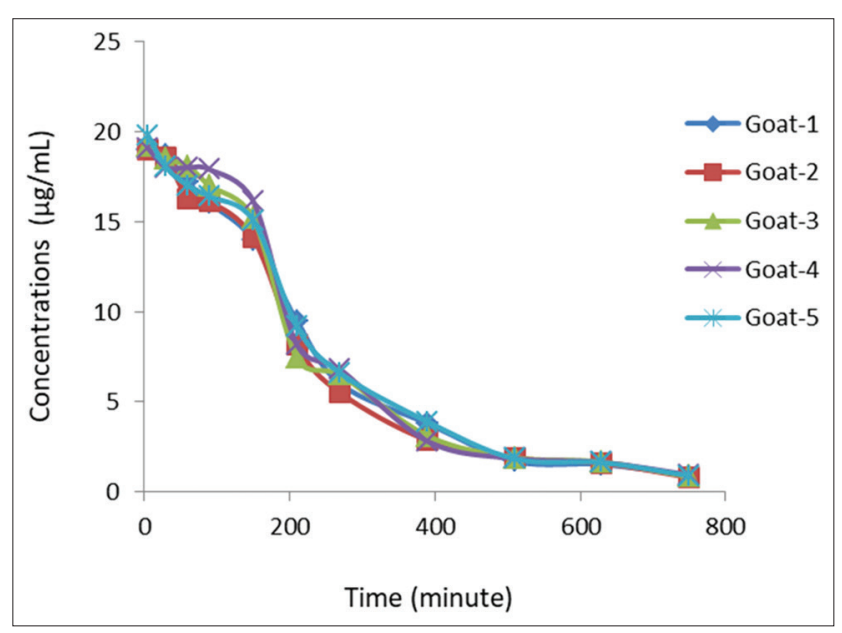

Figure-4: Concentrations of clenbuterol $(\mu \mathrm{g} / \mathrm{mL})$ versus time average $(\mathrm{min})$ for goats administered a single dose intravenously at $0.02 \mathrm{mg}$.

Observations of the data available for clenbuterol in goats indicated that the drug had a rapid onset of action as a type of short-acting $\beta_{2}$-agonist. The elimination phase constant indicated that clenbuterol is eliminated from the body at a slow elimination phase constant. 2-3 days are needed for the drug to disappear from the body after the administration of $0.625 \mathrm{~mL}$ of an injection dose regimen. Commonly, the usual single dose needed to obtain a therapeutic effect is $2.5 \mathrm{~mL}$ for each $100 \mathrm{~kg}$ of body weight. If the animal is given a double dose, there is a risk that the body will have 2 times the amount of drug residue. Thus, a longer time is needed to ensure the absence of a drug residue. Therefore, animals can be safely slaughtered after a drug has passed from the body after treatment. Further, evidence indicated that at $24 \mathrm{~h}$ posttreatment, drug residue on the samples was not found in all of the organs in the liver (Table- $4, \mathrm{p}<0.05$ ). The results showed that clenbuterol was entirely removed from the body of the goat after $24 \mathrm{~h}$. In theory, there is clearance of the clenbuterol. Compared to other researchers, at a dose of $6 \mu \mathrm{g} / \mathrm{kg}$ of body mass given orally once daily over 21 days, male goats (30 kg body weight) had liver residues $0.5-200 \mu \mathrm{g} / \mathrm{L}$. The mean concentrations at $24 \mathrm{~h}$ showed liver residues between $0.023 \mu \mathrm{g} / \mathrm{L}$ and $9.524 \mu \mathrm{g} / \mathrm{L}$ [22]. By comparison with our research as theoretically calculated, the individual goats were divided $9.10^{3}$ times, and we obtained concentrations of $0.000 \mu \mathrm{g} / \mathrm{L}$ for liver residues. Clenbuterol was metabolized in the liver by the conjugation process, and the metabolite will be accumulated in the liver [17]. The clenbuterol metabolite will be easily found in the liver when there is a sufficient amount of drugs. However, other organs will accumulate a proportional amount as follows: Lung $25 \%$, muscle $10 \%$, kidney $50 \%$, and heart $50 \%$, fat $10 \%$, eyes $1 \%$, plasma $50 \%$, urine $50 \%$, and bile $10 \%$ [22]. In this research, the observed amounts were obtained from the plasma and clarification in liver organs. This finding was in accordance with the proportion of the spread of clenbuterol in the body. 
Therefore, the use of clenbuterol as a treatment should proceed with logic and responsible application to the body $[12,27,28]$. If the calculation of withdrawal times was performed using the new method for calculating withdrawal times by substitute of Co in equation 1, with doses administered as accumulate drugs, the results would be satisfactory with no drug residues in all organs [20].

The new method for the design of mathematical models was explained in equation 2. Prediction using the equation 2 for determination of withdrawal times as describe at below is easy to apply and suitable for all species or all of the veterinary drugs, although they need data on the elimination half-life for all of the drugs. The difference between equation 1 and equation 2 is the highest concentration of the drug in the body, as follows: Equation 1, the highest concentration at attributes $\mathrm{Co}$; in equation 2 , the highest concentration was the amount of doses given (dose).

Withdrawal time $=\frac{\mathrm{T}_{1 / 2^{2}} \times\left(\mathrm{LnR} \times \text { Dose }-\mathrm{LnC}_{\lim }\right)}{\mathrm{Ln} 2} \times \mathrm{SF}$

In many countries, the use of clenbuterol requires a veterinarian prescription because it is a hazardous drug and is very easily abused. However, recommendations for the legal use of clenbuterol are safe, especially for animals that will be consumed by humans [22,29-31]. These animals include not only goat species but also other polygastric species, including sheep and cows. This study did not specify residual clenbuterol levels in the animal body but did determine a safe condition that was free of the clenbuterol residues after being given in therapeutic doses [32].

\section{Conclusion}

Evidence showed a safe withdrawal time of $0.02 \mathrm{mg}$ clenbuterol in a formula of $0.625 \mathrm{~mL}$ of an injection dose regimen in goats for 2 days, $13 \mathrm{~h}$, and $12 \mathrm{~min}$ at the $2^{\text {nd }} \mathrm{SF}$ or 3 days, $1 \mathrm{~h}$, and $58 \mathrm{~min}$ at the $3^{\text {rd }}$ SF. These research results are recommended for application to other polygastric species, such as cows and sheep. However, the administration of double doses must be advantageous in research, especially at level concentrations of the drug in the plasma and residues of the drug in the liver.

\section{Authors' Contributions}

LM was a research coordinator and drafted the manuscript, $\mathrm{BH}$ assessed the validation method, and TIR carried out a health analysis of the goats. All of the authors read and approved the final manuscript.

\section{Acknowledgments}

This study was sponsored by The Ministry of Research, Technology and Higher Education of Republic of Indonesia at the program: Research Competence 2 years programs 2016-2017 by Grant No: 004/ADD/SP2H/LT/DRPM/VIII/2017. The authors are grateful to the staff of the Institute Tropical
Disease Research Center Universitas Airlangga for their generous cooperation.

\section{Computing Interests}

The authors declare that they have no competing interests.

\section{References}

1. Grimmer, N.M., Gimbar, R.P., Bursua, A. and Patel, M. (2016) Rhabdomyolysis secondary to clenbuterol use and exercise. J. Emerg. Med., 50: e71-e74.

2. Liu, X., Grandy, D.K. and Janowsky, A. (2014) Ractopamine, a livestock feed additive, is a full agonist at trace amine-associated receptor 1. J. Pharmacol. Exp. Ther., 350: 124-129.

3. Onishchenko, G.G., Popova, A., Tutel'ian, V.A., Zaitseva, N.V., Khotimchenko, S.A., Gmoshinskii, I.V., Sheveleva, S.A., Rakitskii, V.N., Shur, P.Z., Lisitsyn, A.B. and Kir'ianov, D.A. (2013) About the human health safety estimation of ractopamine intake together with the food. Vest. Ross. Akad. Med. Nauk, 6: 4-8.

4. Centner, T.J., Alvey, J.C. and Stelzleni, A.M. (2014) Betaagonists in livestock feed: Status, health concerns, and international trade. J. Anim. Sci., 92: 4234-4240.

5. Guddat, S., Fußhöller, G., Geyer, H., Thomas, A., Braun, H., Haenelt, N., Schwenke, A., Klose, C., Thevis, M. and Schänzer, W. (2012) Clenbuterol-regional food contamination a possible source for inadvertent doping in sports. Drug Test. Anal., 4: 534-538.

6. Li, L., Tang, C., Zhang, J., Zhao, Q. and Zhang, K. (2016) The potential of various living tissues for monitoring clenbuterol abuse in food-producing chinese Simmental beef cattle. J. Anal. Toxicol., 40: 72-77.

7. Sakai, N., Sakai, M., Haron, D.E., Yoneda, M. and Mohd, M.A. (2016) Beta-agonist residues in cattle, chicken and swine livers at the wet market and the environmental impacts of wastewater from livestock farms in Selangor State, Malaysia. Chemosphere, 165: 183-190.

8. Groot, M.J., Lasaroms, J.J., van Bennekom, E.O., Van Hende, J. and Nielen, M.W. (2013) Possible contamination with clenbuterol from treated veal calves to untreated pen mates. Food Additives Contaminants. A Chem. Anal. Control Expos. Risk Assess., 30: 1063-1067.

9. Guo, P., Luo, Z., Xu, X., Zhou, Y., Zhang, B., Chang, R., Du, W., Chang, C. and Fu, Q. (2017) Development of molecular imprinted column-on line-two dimensional liquid chromatography for selective determination of clenbuterol residues in biological samples. Food Chem., 217: 628-636.

10. Parr, M.K., Blokland, M.H., Liebetrau, F., Schmidt, A.H., Meijer, T., Stanic, M., Kwiatkowska, D., Waraksa, E. and Sterk, S.S. (2017) Distinction of clenbuterol intake from drug or contaminated food of animal origin in a controlled administration trial-the potential of enantiomeric separation for doping control analysis. Food Addit. Contam. A. Chem. Anal. Control Exposure Risk Assessment, 34: 525-535.

11. Lazuardi, M., Wahyudi, M.T. and Munier, R.S. (2013) Re-evaluate interrelationship dose-response of diminazene aceturate against to infected mice of Trypanosoma Evansi Bangkalan isolates. J. Vet., 14: 173-177.

12. Lazuardi, M. (2016) Bagian Umum Ilmu Farmasi Veteriner. Ghalia Indonesia Press, Jakarta, Indonesia.

13. Giannetti, L., Ferretti, G., Gallo, V., Necci, F., Giorgi, A., Marini, F., Gennuso, E. and Neri, B. (2016) Analysis of beta-agonist residues in bovine hair: Development of a UPLC-MS/MS method and stability study. J. Chromatogr. B, 1036-1037: 76-83.

14. Lazuardi, M. and Bambang, H. (2016) LC ESI-MS and FT-IR analysis of Dendrophthoe pentandra L. Miq Leaf methanolic extracts to identify compounds with progesterone-like effects. Pak. J. Nutr., 15: 274-282. 
15. Teotia, D., Saini, S.S., Gaid, M., Beuerle, T., Beerhues, L. and Sircar, D. (2016) Development and validation of a new HPLC method for the determination of biphenyl and dibenzofuran phytoalexins in Rosaceae. J. Chromatogr. Sci., 54: 918-922.

16. Lazuardi, M. and Bambang, H. (2017) High-performance liquid chromatography ultraviolet-photodiode array detection method for aflatoxin $\mathrm{B}(1)$ in cattle feed supplements. Vet. World, 10: 932-938.

17. Yan, K., Zhang, H., Hui, W., Zhu, H., Li X., Zhong F., Tong, X. and Chen, C. (2016) Rapid screening of toxic salbutamol, ractopamine, and clenbuterol in pork sample by high-performance liquid chromatography-UV method. $J$. Food Drug Anal., 24: 277-283.

18. Poudel, A., Kim, S.G., Lamichhane, R., Kim, Y.K., Jo, H.K. and Jung, H.J. (2014) Quantitative assessment of traditional oriental herbal formulation Samhwangsasim-tang using UPLC technique. J. Chromatogr. Sci., 52: 176-185.

19. Asberg, D., Nilsson, M., Olsson, S., Samuelsson, J., Svensson, O., Klick, S., Ennis, J., Butterworth, P., Watt, D., Iliadou, S., Karlsson, A., Walker, J.T., Arnot, K., Ealer, N., Hernqvist, K., Svensson, K., Grinell, A., Quist, P.O., Karlsson, A. and Fornstedt, T. (2016) A quality control method enhancement concept-Continual improvement of regulatory approved QC methods. J. Pharm. Biomed. Anal., 129: $273-281$.

20. Lazuardi, M., Restiadi, T.I. and Bambang, H. (2017) Calculated Withdrawal Time by lazuardi Equation Method. In: Prosiding/Proceeding: Musyawarah Nasional ke III Asosiasi Farmakologi dan Farmasi Veteriner Indonesia = $3^{\text {rd }}$ National Conference of Indonesia Veterinary Pharmacy and Pharmacology Association. P4IPVI, Surabaya. p41-43.

21. de Oliveira, M.A., Pires, F.R., Ferraco, M. and Belo, A.F. (2014) The validation of an analytical method for sulfentrazone residue determination in soil using liquid chromatography and a comparison of chromatographic sensitivity to millet as a bioindicator species. Molecules, 19: 10982-10997.

22. Zhao, Z., Yao, T., Qin, Y., Yang, X., Li, J., Li, J. and Gu, X. (2015) Clenbuterol distribution and residues in goat tissues after the repeated administration of a growth-promoting dose. J. Anal. Toxicol., 39: 465-471.
23. Andac, SC. (2016) Determination of drugs by online column-switching liquid chromatography. J. Chromatogr. Sci., 54: 1641-1647.

24. Knych, H.K., Mitchell, M.M., Steinmetz, S.J. and McKemie, D.S. (2014) Detection, pharmacokinetics and cardiac effects following administration of clenbuterol to exercised horses. Equine Vet. J., 46: 380-385.

25. Yang, Y.G., Song, L.X., Jiang, N., Xu, X.T., Di, X.H. and Zhang, M. (2015) Pharmacokinetics of ambroxol and clenbuterol tablets in healthy Chinese volunteers. Int. J. Clin. Exp. Med., 8: 18744-18750.

26. Fernández-Varón, E., Cárceles-García, C., SerranoRodríguez, J.M. and Cárceles-Rodríguez, C.M. (2016) Pharmacokinetics (PK), pharmacodynamics (PD), and PK-PD integration of ceftiofur after a single intravenous, subcutaneous and subcutaneous-LA administration in lactating goats. BMC Vet. Res., 12: 232-242.

27. Lazuardi, M. and Sikumbang, R. (2010) Biofarmasetik dan Farmakokinetik Klinik Medis Veteriner. Ghalia Pressk, Jakarta, Indonesia.

28. Hsiao, P.F., Chang, S.K., Hsu, T.H., Li, K.P. and Chou, C.C. (2016) Pharmacokinetics and tissue depletion of doxycycline administered at high dosage to broiler chickens via the drinking water. Acta Vet. Hung., 64: 472-481.

29. Kissell, L.W., Leavens, T.L., Baynes, R.E., Riviere, J.E. and Smith, G.W. (2015) Comparison of pharmacokinetics and milk elimination of flunixin in healthy cows and cows with mastitis. J. Am. Vet. Med. Assoc., 246: 118-125.

30. Lust, E.B., Barthold, C., Malesker, M.A. and Wichman, T.O. (2011) Human health hazards of veterinary medications: Information for emergency departments. J. Emerg. Med., 40: 198-207.

31. Li, L., Zhang, J., Tang, C. and Zhao, Q. (2014) Accumulation of clenbuterol residues in the hair of Chinese Simmental beef cattle during and after treatment. J. Anal. Toxicol., 38: 52-56.

32. Spiller, H.A., James, K.J., Scholzen, S. and Borys, D.J. (2013) A descriptive study of adverse events from clenbuterol misuse and abuse for weight loss and bodybuilding. Substain. Abus., 34: 306-312. 